\title{
Henry James Conferences Konferencje poświęcone Jamesowi
}

DOI: http://dx.doi.org/10.12775/LC.2017.024

\section{A) 1-6 June 1993 - New York, USA}

"Henry James Sesquicentennial Conference" (the First International Conference of The Henry James Society), organised by The Henry James Society ${ }^{1}$ and New York University.

\section{B) 5-9 July 2002 - Paris, France}

"Henry James Today" (the Second International Conference of The Henry James Society), organised by The Henry James Society and The American University of Paris.

\section{C) 2-3 July 2004 - Aix-en-Provence, France}

"The International Henry James Conference," organised by the Université de Provence.

D) 12-15 July 2005 - Venice, Italy

"Tracing Henry James" (the Third International Conference of The Henry James Society), organised by The Henry James Society and American International University.

E) 29 May 2007 - Salem, Massachusetts, USA

"Reading Henry James Conference," organised by Salem State College.

F) 9-13 July 2008 - Newport, Rhode Island, USA

"Jamesian Strands" (the Fourth International Conference of The Henry James Society), organised by The Henry James Society and Salve Regina University.

\section{G) 3-5 April 2009 - Paris, France}

"Henry James's Europe: Cultural (Re)appropriations and Transtextual Relations" (the First International Conference of The European Society of Jamesian Studies), organised by The European Society of Jamesian Studies and The American University of Paris.

1 The Henry James Society also supports Henry James sessions at The American Literature Association annual conference and at The Modern Language Association convention. 
H) 22-23 October 2010 - Paris, France

"Henry James and the Poetics of Duplicity" (the Second International Conference of The European Society of Jamesian Studies), organised by The European Society of Jamesian Studies and The American University of Paris.

I) 7-10 July 2011 - Rome, Italy

"Transforming Henry James" (the Fifth International Conference of The Henry James Society), organised by The Henry James Society and John Cabot University.

\section{J) 27 August 2011 - Kobe, Japan}

The First Meeting of Jamesian Studies in Japan: “On translation," organised by Kobe City University of Foreign Studies.

\section{K) 26 June 2012 - Oxford, England}

"A Stray Savage in Oxford: A Henry James Centenary Symposium," organised by St. Anne's College, Oxford University.

\section{L) 29 June-1 July 2012 - London, England}

"Placing Henry James," organised by the University of Notre Dame, University College London, the University of Cambridge, The Center for Henry James Studies (Creighton University), and The Henry James Society.

\section{M) 1 September 2012 - Tokyo, Japan}

The Second Meeting of Jamesian Studies in Japan: “Queer Theory and Henry James," organised by Aoyama Gakuin University.

\section{N) 26-28 April 2013 - Toruń, Poland}

"Henry James: His Great Wars and Battles," organised by Nicolaus Copernicus University in Torun and The Center for Henry James Studies (Creighton University).

O) 9-10 May 2013 - Ankara, Turkey

“International Henry James Conference," organised by Başkent University.

\section{P) 31 August 2013 - Kobe, Japan}

The Third Meeting of Jamesian Studies in Japan: “Recent James Studies in Japan," organised by Kobe City University of Foreign Studies.

\section{Q) 16-19 July 2014 - Aberdeen, Scotland}

"The Real Thing Henry James and the Material World" (the Sixth International Conference of The Henry James Society), organised by The Henry James Society and the University of Aberdeen.

\section{R) 30-31 August 2014 - Kita-Kyushu, Japan}

The Fourth Meeting of Jamesian Studies in Japan: "James's Culture Criticisms in His Novelles,” organised by Kita-Kyushu City University. 


\section{S) 29-30 August 2015 - Tokyo, Japan}

The Fifth Meeting of Jamesian Studies in Japan: Forum on "The James Family and Translations," organised by Hitotsubashi University.

\section{T) 14-16 April 2016 - London, England}

"Henry James and Memory," organised by The Eccles Centre for American Studies at The British Library.

\section{U) 2-9 May 2016 - Genoa, Italy}

"Remembering Henry James" - a series of artistic events and a session on Henry James.

\section{V) 9-11 June 2016 - Waltham and Cambridge, Massachusetts, USA}

"Commemorating Henry James / Commemoration in Henry James," organised by The Henry James Society, Brandeis University and the Haughton Library (Harvard University).

\section{W) 3-4 September 2016 - Kyoto, Japan}

The Sixth Meeting of Jamesian Studies in Japan: Forum on "Henry James and Painting," organised by Kyoto University.

\section{X) 20-22 October 2016 - Paris, France}

"Reading James in the Twenty-First Century: Heritage and Transmission" (the Third International Conference of The European Society of Jamesian Studies), organised by The European Society of Jamesian Studies and The American University of Paris.

\section{Y) 28-30 October 2016 - Beijing, China}

"Symposium on 'Understanding Henry James,” organised by Renmin University, Beijing.

\section{Z) 5-8 June 2017 - Seoul, South Korea}

"Jamesian Cultural Anxiety in the East and in the West," organised by the Henry James Society of Korea. 